$1(32) / 2016$

\author{
Monika Wiśniewska-Kin \\ Uniwersytet Łódzki \\ monikawk@uni.lodz.pl
}

\title{
Dziecięce rozumienie świata - w poszukiwaniu uzasadnień postępowania badawczego
}

\begin{abstract}
Summary
Understanding the world from the perspective of children

Reflecting on the understanding of the world from the perspective of children is significant for several reasons. First, it allows us to examine the kind of thinking and actions of children which is of an interpretative nature: it reveals not only the child's personal knowledge, but above all, the ways of understanding, categorising and evaluating an ambiguous and often conflicted reality. It also provides an opportunity to reconstruct the cognitive skills manifested in the verbal and non-verbal reactions of children put in front of an organised problematic situation. In view of such a conclusion, it is worth taking the time to analyse the complex problem: how children perceive the world and how to reconstruct in practice children's processes associated with understanding, categorising, and evaluating the world.
\end{abstract}

Słowa kluczowe: wczesna edukacja, rozwój dziecka, rozumienie, kategoryzacja, wartościowanie

Keywords: early education, child's development, understanding, categorising, evaluating

Refleksja nad rozumieniem świata z perspektywy dzieci jest istotna z kilku powodów. Po pierwsze, umożliwia zbadanie takiego rodzaju myślenia i działania dzieci, który ma charakter interpretacyjny: odsłania nie tylko dziecięcą wiedzę osobistą, ale przede wszystkim sposoby pojmowania, kategoryzowania i wartościowania niejednoznacznej, często skonfliktowanej rzeczywistości. Daje również możliwość zrekonstruowania zdolności poznawczych uzewnętrzniających się w werbalnych i pozawerbalnych reakcjach dzieci postawionych przed zorganizowaną sytuacją problemową.

Po drugie, refleksja taka pozwala sformułować postulaty i zarysować mapy kierunków, które wskazują możliwości wyzwalania tworzonych w młodym umyśle językowych obrazów zakotwiczonych w kulturze i w osobistym doświadczeniu. Uruchamia zatem przestrzeń do myślenia o koniecznych zmianach w szkole, związanych z innym niż dotychczas pojmowaniem dziecięcego rozumienia świata. Dostrzega je, próbuje rozpoznać i ocenić D. Klus-Stańska w publikacji Światy dziecięcych znaczeń (2004). Dowodzi w niej, że dzieci nieustannie konstruują swoją wiedzę zarówno o otaczającej rzeczywistości, jak i o sobie. Znaczna część tej wiedzy jest jednak słabo lub w ogóle nieuświadomiona, co 
powoduje, że może w dużym stopniu nie pokrywać się z tym, co świadomie przekazujemy dzieciom w procesach kształcenia jako tzw. wiadomości (tamże: 7).

Konieczna staje się więc ponowna dyskusja o dziecięcym rozumieniu świata, którą spróbuję zainicjować przez przywołanie rozważań teoretycznych poświęconych temu zagadnieniu, ukazanie trudności metodologicznych związanych z badaniem dynamicznego zjawiska, jakim jest rozumienie świata z perspektywy dzieci z jego wielorakimi uwikłaniami kulturowymi, oraz wskazanie kierunku dalszych poszukiwań podejmowanych z perspektywy paradygmatu kognitywistycznego.

Artykuł ten ma więc wyraźnie teoretyczny charakter. Zmierza do ustalenia istoty analizowanego zjawiska, a także uporządkowania rozważań, które wskazują nowe możliwości nauczania rozumianego nie jako kierowanie procesem przyswajania wiadomości, rozwijania umiejętności i wykształcania nawyków, lecz jako wyzwalanie i rozwijanie zdolności poznawczych, kształtowanie postaw badawczych, a nade wszystko wzbudzanie gotowości do określania własnego miejsca w świecie realnym i w świecie wartości.

\section{Docieranie do źródel i inspiracji teoretycznych}

Zainteresowanie problemem rozumienia nie ma prostych odniesień do zagadnień podejmowanych w tradycji badań pedagogicznych. Prowadzone w tym obszarze badania nadal należą do rzadkich (Klus-Stańska 2004; Wasilewska 2007; Wiśniewska-Kin 2007, 2009; Szczepska-Pustkowska 2011). Podobne opinie formułowane są również w obszarze badań psychologicznych. Na przykład W. Szewczuk w Psychologii rozumienia (1968) dowodzi, że ,przez wiele dziesiątek lat rozmyślano nad rozumieniem, przez niewiele lat badano rozumienie. (...) Jest rzeczą charakterystyczną, że u wielu psychologów, którzy zajmowali się rozumieniem nawet $\mathrm{w}$ sensie badawczym czy wręcz eksperymentalnym, nie zostało ono jako zagadnienie wyodrębnione i postawione jasno w sposób teoretyczny" (tamże: 59).

Natomiast w świadomości społecznej nie brakuje stereotypów na ten temat. W ich repertuarze znajduje się stereotyp rozumnego dziecka, które w opinii dorosłych (nauczycieli i rodziców) utożsamiane jest raczej z pilnym, posłusznym, piątkowym uczniem, zaś w opinii rówieśników oznacza zwykle bycie „kujonem”, który swój wolny czas spędza nad książkami. Taki obraz utrwala definicja słownikowa, zgodnie z którą „dziecko może stawać się coraz rozumniejsze" (Szymczak 1995), a zatem z natury dziecko nie jest rozumne i dopiero $\mathrm{w}$ toku rozwoju przechodzi z niższego do wyższego poziomu rozwoju, zgodnie z linearną naturą tegoż. Rozwój determinuje też jego konieczna instytucjonalizacja (Klus-Stańska 2015: 16).

Ugruntowało się myślenie o tym, że kategoria rozumienia zarezerwowana jest dla badań prowadzonych na pograniczu lingwistyki lub psychologii. W świetle lingwistycznej teorii tekstu uwaga badaczy skierowana jest na znaczenie procesu rozumienia zawartego w akcie czytania tekstu. Ustalono, że badania dotyczące czytania powinny zmierzać do wyjaśnienia procesów rozumienia objętych aktem czytania. Sprawiło to, że rozwinęly się badania dotyczące rodzajów wnioskowania aktywizowanego w procesie rozumienia tek- 
stu, ich charakterystycznych cech oraz - co najważniejsze - znaczenia umiejętności aktywizowania procesów wnioskowania w procesie recepcji tekstu (Kliś 1995).

Natomiast w kręgu badań psychologicznych ,rozumienie" (understanding) jest w odróżnieniu od „rozumowania” (reasoning) rozpatrywane jako:

- proces uchwycenia znaczenia słów, zdań, zdarzeń, sądów;

- nieuchwytny, intuicyjny proces, za pomocą którego daje się pojąć głębokie, istotne znaczenie danego zdarzenia, pojęcia i myśli;

- postawa pełna zrozumienia i współczucia wobec innych osób, a zwłaszcza zrozumienia ich punktu widzenia na jakieś kwestie lub ich przekonań i wierzeń;

- hipotetyczna własność umysłowa (w starszych opracowaniach), której funkcją jest umożliwienie zrozumienia znaczenia danej rzeczy (Reber, Reber 2005: 669).

Rozumienie pojmuje się także w kontekście procedury badawczej, która przeciwstawiana jest wyjaśnianiu (Siuta 2005: 247-248). W tym kontekście nie sposób pominąć definicji rozumienia jako „,czynnego procesu konstruowania reprezentacji, polegającego na interpretacji odbieranych informacji zgodnie z systemem posiadanej wiedzy i na włączaniu tej informacji w ów istniejący już system" (Kurcz 1987: 308). Z przytoczonego objaśnienia wynika, że efektem procesu rozumienia jest reprezentacja, czyli „coś, co jest konstruowane przez umysł człowieka i za pośrednictwem czego poznawana jest rzeczywistość" (Maruszewski 1996: 14). Podmiot ma dostęp tylko do tworzonych przez siebie reprezentacji, a przez nie uzyskuje dostęp do świata.

„Reprezentacje te, podobnie jak język, są przezroczyste, to znaczy jednostka nie zdaje sobie sprawy z tego, że poznaje własne reprezentacje, a dopiero za ich pośrednictwem świat. Nie można więc mówić, czy poznanie jest trafne, czy też nie, ponieważ trafność dotyczy relacji między tym jak przedstawia się świat reprezentowany a tym, jak przedstawia się świat rzeczywisty. Ta relacja jest faktycznie relacją między światem zewnętrznym lub wewnętrznym a schematem, który go przedstawia" (Maruszewski 2002: 68).

Wynika z tego, że podmiot nadaje znaczenia nowo poznawanym elementom rzeczywistości, konfrontując je z wewnętrznym schematem, który stanowi swoisty pomost interpretacyjny. Internalizowane znaczenia początkowo otwarte są na modyfikacje, jednak w miarę ich potwierdzania utrwalają się coraz mocniej i zaczynają stanowić określony osobisty „teoretyczny model świata”. Sens tego świata, początkowo uproszczony i fragmentaryczny, staje się z czasem wieloaspektowy i względnie spójny (Klus-Stańska 2004: 18).

W wyniku podjętych rozważania rodzi się pytanie: Jeśli nie sposób uznać, czy poznanie jest trafne czy też nie, jeśli nie jest możliwe przeprowadzenie „zobiektywizowanej” wiwisekcji dziecięcego oglądu świata, zmierzającej do ustalenia „poprawnej” wersji rozumienia rzeczywistości, to jakie istnieją kryteria oceny przebiegu procesu rozumienia? 


\title{
Obiektywne i subiektywne kryteria rozumienia
}

Na gruncie psychologii poznawczej powstały liczne modele teoretyczne wyjaśniające przebieg procesu rozumienia oraz ewolucję, jaka dokonała się w tej kwestii (por. Szewczuk 1968; Dobrowolski 1992; Kliś 2000; Kurcz 1987; Kurcz, Polkowska 1990; Maruszewski 2011). We wczesnych koncepcjach dokonano rozróżnienia subiektywnych i obiektywnych kryteriów rozumienia. Pierwsze z nich objaśniane były jako poczucie rozumienia, które

\begin{abstract}
„może być zgodne z obiektywnym kryterium, może być równoznaczne z faktycznym rozumieniem, ale może również nie być z nim równoznaczne, co więcej, może powstawać w sytuacji częściowego lub wręcz całkowitego nierozumienia. W tych ostatnich przypadkach należy mówić o pozornym rozumieniu. Pozorność jednak uwidacznia się dopiero z chwilą, gdy spełnione zostaną obiektywne kryteria rozumienia: działania lub wypowiedzi (...), które mogą przybierać rozmaitą postać w zależności od rodzaju przedmiotu rozumienia i mogą występować w różnych wzajemnych kombinacjach” (Szewczuk 1968: 71-73).
\end{abstract}

Okazuje się zatem, że początkowo kwestia poprawności rozumienia ujmowana była w sposób normatywny, poprzez odniesienie do ustalonego arbitralnie zewnętrznego kryterium (określającego na przykład poziom rozumienia: pełny, niepełny, lub jego brak) lub kryterium wewnętrznego (rozumienie rozpatrywane w kontekście prawidłowości rozwojowych, wyznaczonych dojrzewaniem struktur poznawczych).

Współcześnie taki sposób ujęcia zjawiska rozumienia został na gruncie psychologii poddany krytyce (Lee, Gupta 2002). Przyjmuje się, że mówienie o poprawności rozumienia jest usprawiedliwione tam, gdzie chodzi o sytuację komunikowania lub przekazywania informacji, które mają umożliwić podjęcie decyzji lub działanie. Natomiast tam, gdzie rozumienie dotyczy obrazu rzeczywistości, należy zakładać subiektywizm podmiotu rozumiejącego i nie oceniać rozumienia w kategoriach poprawności (Szalkowska 2008: 39-40).

W kontekście tych rozważań mówi się nawet o starym i nowym paradygmacie rozumienia (Hörman 1994: 93-99). Zgodnie z pierwszym rozumienie utożsamia się z odczytywaniem znaczenia znaków, na co nie wpływa sytuacja podmiotu czy posiadana przez niego wiedza wykraczająca poza znaczenie tekstu. Natomiast zgodnie z drugim paradygmatem, rozumienie odnosi się do tego, co podmiot ma na myśli (Szalkowska 2008: 40). Chodzi tu o jego subiektywny sposób odczytania znaczenia przekazu.

Takie podejście jest bliskie swoistości dziecięcego procesu rozumienia. Dziecko bowiem nie myśli dokładnie tego, co dorośli użytkownicy języka mu zakomunikowali. Już od najwcześniejszych kontaktów z otaczającym światem podejmuje nieustanne próby pojmowania rzeczywistości. Dobitnie o tym problemie mówi D. Klus-Stańska (2004): „dydaktyczna wiara, że dzieciom po prostu wystarczy dobrze wyjaśnić świat, by go rozumiały w sposób, jaki uznaliśmy za poprawny (cokolwiek termin ,poprawny” miałyby znaczyć), wydaje się nie do przyjęcia” (tamże: 17). W obliczu tej konstatacji, warto pochylić się nad złożonym problemem dotyczącym sposobów rekonstruowania dziecięcych procesów związanych z rozumieniem, kategoryzacją i wartościowaniem świata. 


\section{Rekonstruowanie dziecięcego rozumienia świata - problemy natury metodologicznej}

Aby dokonać interpretacji dziecięcego rozumienia uobecniającego się w werbalnych i pozawerbalnych wypowiedziach dzieci, dorosły użytkownik języka powinien rozpoznać to, co dzieje się w umyśle dziecka, czyli w zasadzie to, co jest niemożliwe do poznania. Jak bowiem uchwycić proces tworzenia się swoistych obrazów w umyśle?

Próby odpowiedzi na to pytanie nie dostarczają łatwych odpowiedzi. Nowe dane empiryczne uzyskiwane za pomocą technik neuroobrazowania, takich jak: tomografia pozytonowa, funkcjonalny rezonans magnetyczny czy EEG, wzbogacają naszą wiedzę o funkcjonowaniu mózgu (Maruszewski 2011: 25). Zdarza się jednak również, że eksperymenty nie zawsze przynoszą oczekiwane rezultaty. Na przykład, zastosowanie niektórych metod obrazowania pracy mózgu wymaga od badanych pozostawania w bezruchu, ponieważ minimalizuje to zakłócenia pomiarowe. Natomiast w takich warunkach kłopotliwe może być badanie szybkości reakcji motorycznych czy precyzyjnej ekspozycji bodźców (Wierzchoń i in. 2012). Ciągle zatem daleko jeszcze do rozstrzygnięcia fundamentalnych problemów teoretycznych związanych z pracą umysłu, zwłaszcza małych dzieci (Gopnik i in.: 145-183).

Wydaje się więc, że dla pedagoga bezradnego wobec tajemnicy ludzkiego umysłu dostępne pozostają jedynie narzędzia opisu, płynące z organizacji tekstu w jego dynamicznej postaci. Co to oznacza w sensie praktyki interpretacyjnej? Językoznawcy kognitywni dowodzą, że w polu zainteresowań powinno pozostać znaczenie, ponieważ proces nadawania znaczeń, uwarunkowany kulturowo i społecznie ale też jednostkowo (indywidualnie), odzwierciedla wymiary dziecięcego bycia w świecie. Kognitywny opis znaczenia zorientowany jest bowiem na rekonstrukcję sposobu rozumienia wyrażeń językowych przez podmiot mówiący (homo loquens), gdyż to z jego punktu widzenia dokonuje się ogląd i ocena rzeczywistości (Bartmiński, Pajdzińska 2008). Skoro znaczenie jest immanentnie związane z subiektywną w istocie interpretacją jakiejś rzeczywistości pozajęzykowej, to siłą rzeczy semantyka przenosi zainteresowanie z obiektu na subiekty - bada sposoby postrzegania i językowego ujmowania świata w aspekcie podmiotowym.

Docierając do rozumienia znaczeń wybranych obszarów rzeczywistości z perspektywy dzieci, warto więc poszukiwać odpowiedzi na następujące pytania:

1. W jaki sposób w wypowiedziach dziecięcych wspólistnieją dwie przestrzenie: utrwalona w języku i zawarta w wiedzy społecznej?

2. Jakie światy „kryją” się za dziecięcymi sposobami kategoryzacji?

3. W jaki sposób wybór modelu kategoryzacji oraz subiektywnych sposobów wartościowania zjawisk profiluje spojrzenie na świat z perspektywy dzieci?

Zakreślone problemy wskazują kierunki analiz dziecięcego rozumienia. Przyjrzyjmy się bliżej tym kwestiom. 


\section{Rozpoznać dziecięcy proces nadawania znaczeń}

Każde dziecko używa „swojego języka”, który jest wypadkową języka społecznego i indywidualnego. Dokonuje wyboru form językowych dla nadania formy określonemu znaczeniu oraz wyboru znaczenia, do którego może się odnosić napotkana forma (Ożdżyński 1995). Z jednej strony skazane jest więc ono na używanie utrwalonych w języku sposobów odnoszenia znaczeń do form językowych (reguł gramatycznych, semantycznych, pragmatycznych) - z drugiej jednak, tworzy na co dzień, zwłaszcza w swoim najbliższym otoczeniu, osobiste, indywidualne interpretacje często chaotycznej i nieprzewidywalnej rzeczywistości (Bartmiński 2007a). Trafnie problem ten ujmuje D. Klus-Stańska (2004):

„światy dziecięcych znaczeń nie jawią się jako idylliczna kraina baśni, chroniona przed trudami dojrzałego życia, wypełniona beztroską i wspieranym przez dorosłych, rozumnie kierowanym poznawaniem tego, co je otacza. To raczej ryzykowny i obarczony konsekwencjami nieustanny wysiłek pogodzenia sprzeczności i napięć związanych z dekodowaniem napływających informacji, rozbieżnych deklaracji i oczekiwań, niejasnych reguł i niespójności wartości” (tamże: 8).

Dziecięcy proces nadawania znaczeń rozpatrywany jest więc jako sposób poznawania, odkrywania i przeżywania świata, w którym dziecko żyje. Świata nie tylko fizycznego, który go otacza, ale przede wszystkim, niematerialnego, duchowego, który tworzy się w jego umyśle. „Sposób rozumienia odzwierciedla więc dziecięcy świat, dziecięcą osobowość. Wszystko to, co dzieci mówią, i to, jak to mówią, wszystko, co piszą lub rysują, i to, jak to piszą lub rysują, pokazuje kim są i jacy są, jak i co przeżywają" (Martyniuk 2000: 45).

Rozumienie ujawnia się więc w dziecięcych wypowiedziach i tekstach, które w ujęciu W. Martyniuka (tamże) stanowią dialektyczną jedność zdarzenia i znaczenia:

„Zdarzeniem jest to, co mówimy lub piszemy, znaczeniem zaś to, o czym piszemy lub mówimy, to znaczy, do czego odnosimy to, co zostało napisane lub powiedziane. Wypowiadając lub pisząc coś, odnosimy owo coś do swojego świata, to znaczy kierujemy myśl odbiorcy ku pewnym punktom odniesienia w obrębie horyzontów naszego własnego świata. (...) Zrozumieć tekst znaczy więc nadać zdarzeniu, jakim on jest, znaczenie. Hans Georg Gadamer nazywa ten moment fuzją horyzontów (Horizontenverschmelzung) nadawcy i odbiorcy, przypisując procesowi rozumienia rangę epistemologiczną, tzn. prowadzącą do poznania świata" (tamże: 45).

D. Klus-Stańska (2004) proponuje również dokonywać analizy skomplikowanej sieci wpływów towarzyszących procesowi nadawania znaczeń z perspektywy dzieci, czyli - dla przykładu - tego, w jakich warunkach dziecko konstruuje obraz rzeczywistości, jakie przy tym obowiązują ,zasady gry”, kto mówi i kto decyduje o komunikacji. Ten kontekst zewnętrzny jest istotny, ponieważ „dziecko konstruuje obraz rzeczywistości nie tyle słuchając o niej, ile jej doświadczając, co oznacza, że nawet słuchanie jest złożonym sposobem doświadczania siebie i innych, a nie mechanicznym rejestrowaniem cudzych 
wypowiedzi" (tamże: 17). A zatem znaczenie wypowiedzi determinowane jest nie tylko przez jej treść i formę, ale także przez kontekst, w jakim wypowiedź ta jest realizowana, zaś rozumienie tekstu dotyczy nie tylko jego językowej postaci, lecz obejmuje swoim zasięgiem także zjawiska kultury z poziomu potocznego doświadczenia każdego uczestnika społecznego życia. Stało się oczywiste, że język wyprowadzony z wrodzonej kompetencji, oparty jedynie na gotowych strukturach, nie wystarcza do wyrażenia wielu stanów i doznań, oraz nie przystaje do myśli, kiedy chcemy uchwycić, wyjaśnić, opisać coś trudnego, zwłaszcza nieoczywistego.

\section{Zrekonstruować dziecięce sposoby kategoryzowania oraz ustalić zdolności po- znawcze dzieci wyrażające się w języku}

Spostrzeżenia poczynione przy analizie semantycznych cech pojęć badacz może również wykorzystać do analizy dziecięcych sposobów kategoryzowania, ujawniających się podczas opisu znaczenia słowa. Dziecko dokonuje kategoryzacji przedmiotów, biorąc pod uwagę ich naturalne własności. Takie ich pogrupowanie ułatwia mu uporządkowanie doświadczanej percepcyjnie rzeczywistości. W procesie percepcji zwraca uwagę na różne aspekty rzeczy (profiluje inne cechy), dlatego też dany przedmiot może zaliczyć do kilku kategorii. Najczęściej dokonuje subiektywnej kategoryzacji świata, ujmując go w odpowiednie, porządkujące kategorie naturalne, takie jak: rzecz, wydarzenie, miejsce, sposób, czynność, które uwypuklają istotne dla dzieci składniki semantyczne. Dziecko nie może w sposób arbitralny poklasyfikować świata, co wynika ze zróżnicowania wewnętrznego cech semantycznych składających się na znaczenie słowa.

Wykorzystanie różnych sposobów subiektywnego kategoryzowania stwarza możliwość ustalenia zdolności poznawczych dzieci wyrażających się w języku (Langacker 1995):

1. Kategoryzowanie jednych struktur w oparciu o inne.

2. Rozpoznawanie podobieństw między różnymi strukturami.

3. Łączenie prostszych struktur $w$ bardziej złożone.

4. Kategoryzowanie i ujmowanie danej sytuacji na różnych poziomach abstrakcji (schematyzacja).

5. Ustalanie odpowiedniości między elementami znaczenia różnych struktur.

6. Konceptualizowanie tej samej sytuacji na wiele sposobów (obrazowanie) (tamże). Dzieci najczęściej kategoryzują jedne struktury na podstawie innych oraz rozpoznają podobieństwa między różnymi strukturami. Umiejętnościami nabywanymi najpóźniej są ustalanie odpowiedniości między elementami różnych struktur (posługiwanie się metaforami) oraz konceptualizowanie tej samej sytuacji na wiele sposobów (obrazowanie). Zatem badania zdolności poznawczych ujawniających się w języku prowokują do zadawania pytań o to, w jaki sposób dzieci potrafią uchwycić znaczenie metaforyczne, jak interpretują związek między dziedzinami metafory, w jaki sposób tłumaczą jedną dziedzinę metafory przez drugą, a także, w jaki sposób odnajdują podobieństwa i dostrzegają różnice między docelową a źródłową dziedziną metafory.

W rozważnie zorganizowanym badaniu dziecięcego rozumienia świata proponuje się dzieciom takie dziedziny źródłowe, które są już im znane, odwołują się do ich życia, 
a więc: szkołę, sporty, relacje towarzyskie, żywność, pieniądze. Metafory muszą więc występować w znanym dziecku kontekście, co sprzyja zrozumieniu powstałych znaczeń. Badacz, upewniając się, że dzieciom znana jest dziedzina źródłowa metafory, zwraca uwagę na te aspekty, których mają jej użyć, aby skonstruować nową informację. Prowadzi ich do wyobrażenia sobie dziedziny docelowej oraz nadaje kierunek działaniom i myśleniu. Zachęca do dyskutowania o metaforach: podawania przykładów, rozwiązywania problemów opartych na metaforze, stosowania metafory w nowych sytuacjach lub jej rozszerzania poza punkt, w którym zaczyna się ona załamywać.

Wartość badawczą ma także przeanalizowanie trudności uchwycenia więzi motywujących metafory, gdyż czynniki ograniczające rozumienie metafor są różne, np. dla niektórych uczniów wiedza abstrakcyjna, niemająca wizualnego odpowiednika, może się okazać zupełnie nowym rodzajem wiedzy, na którego przyjęcie nie są przygotowani. Nie jest to jednak nieprzekraczalna bariera, przeciwnie: rozpoznanie trudności prowadzi zazwyczaj do pokonania ograniczeń, a dalsze ćwiczenie uelastycznia myślenie, otwiera je na nieoczywistość, niedosłowność i odkrywczość.

\section{Zastosować adekwatne metody opisu znaczenia}

Aby uchwycić proces rozumienia pojęć z perspektywy dzieci, warto posłużyć się metodą eksplikacji cech semantycznych na podstawie podejmowanych przez dzieci prób formułowania definicji. Do weryfikacji znaczenia pojęcia w rozumieniu dzieci może posłużyć definicja słownikowa. Porównanie słownikowej i dziecięcej charakterystyki przedmiotu ukazuje różnice między cechami semantycznymi, istotnymi z punktu widzenia dorosłych użytkowników języka, a cechami ważnymi dla dzieci. Definicja słownikowa nie przekazuje pełnej treści opisującej znaczenie pojęcia, obejmuje jedynie minimum cech definicyjnych. Natomiast definicje dzieci zawierają pełniejszy obraz przedmiotu, ponieważ utrwalają indywidualne wyobrażenia z im związane. Dzieci dokonują bowiem wyboru cech istotnych z ich własnego punktu widzenia, uznają pewne cechy semantyczne przypisane desygnatowi za relewantne, inne natomiast za drugorzędne. Rezygnują z określeń nadrzędnych, natomiast podają cechy charakterystyczne, ujęte w objaśnieniach partonomicznych (co jest częścią czego) i funkcjonalnych (co do czego służy). Opisują też relacje między składnikami konotacji słowa: współwystępowanie cech, uporządkowanie cech na zasadzie następstwa czasowego, związku przyczynowo-skutkowego, odniesienia do pewnych całości (zespołów, kolekcji), a także uporządkowanie cech od tego, co bliższe dziecku, ku temu, co dalsze (Bartmiński 2007a: 48-49). Analiza dziecięcego materiału językowego pozwala więc ustalić wewnętrzną strukturę semantyczną oraz hierarchię cech znaczeniowych w obrębie otwartej definicji pojęcia (Bartmiński, Tokarski 1993).

Rekonstruując proces rozumienia pojęć z perspektywy dzieci poddaje się analizie nie tylko umiejętność przedstawiania cech identyfikujących przedmiot, ale też wskazywanie dodatkowych cech stereotypowych (relacyjnych, funkcjonalnych, lokalizacyjnych, percepcyjnych, atrybutywnych), które stanowią „potoczną teorię pojęcia” (Bartmiński 
2007b). Stereotypy charakteryzują się pełniejszym ujęciem treści znaczeniowej słowa. Zawierają informacje redundantne, na podstawie których badacz może ustalić utrwalone kulturowo sądy, skojarzone z danym pojęciem.

Podczas ustalania stereotypu wytworzonego przez dzieci i porównywania go ze stereotypem utrwalonym w świadomości społecznej, można skorzystać z dwóch wykładników stereotypizacji. Są nimi: (1) powtarzalność charakterystyki przedmiotu w różnych wypowiedziach; (2) utrwalanie tej charakterystyki w języku w znaczeniach słów, dające się uchwycić poprzez analizę wyrazów pochodnych, metafor, frazeologii i przysłów (Bartmiński, Panasiuk 1993: 375).

\title{
Zadbać o klimat badań
}

Chcąc zrozumieć, jak konstruowana jest umysłowa reprezentacja dziecięcych narracji, warto zadbać również o stworzenie dzieciom warunków, w których swobodnie będą mogły konstruować znaczenia. „Migotliwe” uczniowskie znaczenia powinny być interpretowane w sytuacyjnym procesie tworzenia się, a nie za pomocą terminów, które można powszechnie stosować:

\begin{abstract}
„Dzieci i ich wrastanie w kulturę cechuje bowiem niezwykła chłonność intelektualna, wrażliwość, a jednocześnie względne ubóstwo doświadczeń i brak poznawczej „odporności”, jaka pojawia się z chwilą krystalizacji własnych przekonań i wiedzy. Dlatego nabywanie przez nie znaczeń ma swoją specyfikę i unikatowość. Ich badanie jest bardzo trudne z uwagi na bariery komunikacyjne; z dziećmi nie da się swobodnie mówić o znaczeniach. Większe nadzieje badawcze budzi wnikliwa analiza powtarzalnych doświadczeń, jakie są przez nie gromadzone w szczególnie znaczących obszarach życia, i znaków kulturowych, które są im prezentowane" (Klus-Stańska 2004: 7).
\end{abstract}

Aby zobrazować proces narastania znaczeń w świadomości uczniów, można zaproponować dzieciom działania plastyczne, które mogą im ułatwić wypowiedzi, pomóc przezwyciężyć trudności w werbalizowaniu myśli. Kształt graficzny prac jest bowiem dokumentacją aspektu treściowego. Istotnym jego dopełnieniem jest aktywność werbalna w trakcie ich wykonywania: głośne myślenie, zastanawianie się, samorzutne wypowiedzi, zadawanie pytań lub odpowiadanie na nie. Wytwory dzieci są też pomostem między tym, co dostrzegły i zrozumiały, a tym, co umiały o swojej interpretacji powiedzieć. Zgodnie $\mathrm{z}$ tą koncepcją myślenie i mówienie zaczyna się już na poziomie widzenia:

„Językoznawstwo kognitywne wykazało, że język - twór raczej organiczny niż logiczny jest produktem i odzwierciedleniem percepcji zmysłowej, w której zdecydowanie dominuje postrzeganie wzrokowe. Przekazy wizualne, bliższe doświadczeniu wzrokowemu, są więc bardziej elementarne niż twory werbalne, realizowane już w innym medium" (A. Kwiatkowska 2009: 10). 
W przypadku realizacji wizualnych dokonywanych z perspektywy dzieci ważne są: stopień ich abstrakcji (poziom schematyczności), różne rodzaje wyróżnienia oparte na systemie podziału uwagi, np. profilowanie, a także różne aspekty perspektywy, np. punkt widzenia, bliskość elementów, ich kolejność, wielkość. Format przekazu wiąże się z jego dużym ładunkiem emocjonalnym, zgodnie z metaforą pojęciową: „więcej formy to więcej treści” i „duże to ważne” (Kwiatkowska, Jarniewicz 2009).

Z kolei spontaniczna wymiana myśli po zakończeniu konkretyzacji plastycznej oraz indywidualne rozmowy z każdym uczniem pozwalają unikać pułapek w interpretacji rysunków: dziecko informuje nas o czymś w sposób dosłowny, my zaś doszukujemy się ukrytych sensów.

Badania dziecięcych sposobów rozumienia świata dostarczają wielu sygnałów i informacji, które uprawniają do tego, by odrzucić tradycyjny pogląd, sprowadzający uczenie się do rejestrowania, utrwalania i odtwarzania gotowych prawd, oraz bezpodstawne mniemanie o ograniczonych (rozwojowo) dziecięcych kompetencjach poznawczych. Kwestionują też kompromisy dyktowane przez pajdokrację i rozrywkowy model kultury popularnej, karmiącej dziecko bezrefleksyjną wesołością, łatwizną i banałem w przekonaniu, że wszystko, z czym ono obcuje, powinno być lekkie, przyjemne, niezobowiązujące.

Warto zatem przyznać dziecku prawo do uzgadniania sensów i nadawania światu znaczeń w procesie samodzielnego konstruowania wiedzy, przestrzegając jednocześnie przed literalnym podejściem do Piagetowskiej struktury poznawczej dzieci, która spotyka się z dominującym w edukacji modelem transmisji wiedzy i behawioralnie zorientowanym systemem przekonań o uczeniu się. Dziecko staje się obiektem wyuczenia, a nie istotą wyposażoną w bogaty, choć wymagający troskliwego i rozważnego wsparcia aparat poznawczy. Ten „obiekt” jest postrzegany dość instrumentalnie, przede wszystkim jako uczeń, a nie rozwijający się człowiek. Transmisyjna organizacja procesu nauczania powoduje, że nauczyciel może nigdy nie doświadczyć dziecięcego sposobu rozumienia świata.

Dla zamknięcia rozważań można by za D. Klus-Stańską (2004) sformułować następującą konstatację:

„Rzeczy i sytuacje, z którymi dziecko się styka po raz pierwszy, nie są po prostu białą plamą, czekającą na ,poprawne” zdefiniowanie przez kogoś, „kto już to zna”. Dziecko nadaje mu znaczenia przybliżone, kierując się podobieństwem percepcyjnym, intelektualnym bądź emocjonalnym, określanym na bazie dotychczasowych doświadczeń. Każdorazowo definiuje sytuacje i uzgadnia znaczenia mu nadawane. Konstrukty znaczeniowe, jakie wytwarza, są zindywidualizowane - choć ulokowane w polu kulturowej wspólnoty znaczeń i adekwatności praktycznej; mogą też być po prostu błędne, np. wskutek nietrafnej ekstrapolacji z jednych obszarów rzeczywistości na inne. Zawsze jednak są wynikiem mentalnej negocjacji znaczeń wynikających z doświadczania świata poprzez jego obserwację, działanie w nim i uczestniczenie w procesach komunikacji” (tamże: 18).

Czy znajdziemy w sobie gotowość, aby rozpoznać dziecięce sposoby rozumienia świata? 


\section{Bibliografia}

Bartmiński J. (2007a), Językowe podstawy obrazu świata. Lublin, Wydawnictwo UMCS.

Bartmiński J. (2007b), Stereotypy mieszkaja w języku. Studia etnolingwistyczne. Lublin, Wydawnictwo UMCS.

Bartmiński J., Pajdzińska A. (red.) (2008), Podmiot w języku i kulturze. Lublin, Wydawnictwo UMCS.

Bartmiński J., Panasiuk J. (1993), Stereotypy językowe. W: J. Bartmiński (red.), Współczesny język polski. Encyklopedia kultury XX wieku, t. 2. Wrocław, Wydawnictwo Wiedza o Kulturze.

Bartmiński J., Tokarski R. (red.) (1993), O definicjach i definiowaniu. Lublin Wydawnictwo UMCS.

Dobrowolski R. (1992), Rozumienie tekstu. W: M. Materska, T. Tyszka (red.), Psychologia i poznanie. Warszawa, PWN.

Gopnik A., Meltzoff N.A., Kuhl K.P. (2004), Naukowiec w kolysce. Czego o umyśle ucza nas mate dzieci. Poznań, Wydawnictwo Media Rodzina.

Kliś M. (1995), Rozumienie struktury tekstu a zdolności poznawcze uczniów. W: J. Trempała (red.), Rozwijajacy się czlowiek w zmieniajacym się świecie. Bydgoszcz, Wydawnictwo Uczelniane WSP w Bydgoszczy.

Kliś M. (2000), Modele umysłowej reprezentacji czytanego tekstu. „Psychologia Wychowawcza”, $2-3$.

Klus-Stańska D. (2004), Światy dziecięcych znaczeń. Warszawa, Wydawnictwo Akademickie ŻAK.

Klus-Stańska D. (2015), Wyjść poza instytucjonalna standaryzację dziecka. Nowe inspiracje teoretyczne dla wczesnej edukacji. „Studia Pedagogiczne”, LXVIII.

Kurcz I. (1987), Język a reprezentacja świata w umyśle. Warszawa, PWN.

Kurcz I., Polkowska A. (1990), Interakcyjne i autonomiczne przetwarzanie informacji językowych. Na przykładzie procesu rozumienia tekstu czytanego na głos. Wrocław, Ossolineum.

Kwiatkowska A., Jarniewicz J. (red.) (2009), Między obrazem a tekstem. Łódź, Wydawnictwo UŁ.

Langacker R.W. (1995), Symboliczny charakter gramatyki. W: H. Kardela (red.), Wykłady z gramatyki kognitywnej. Lublin, Wydawnictwo UMCS.

Lee V., Gupta P.D. (red.) (2002), Children's Cognitive and Language Development. Oxford.

Martynik W. (2000), Interpretacja tekstów w procesie ksztatcenia językowego. „Nowa Polszczyzna", 5 (20).

Maruszewski T. (1996), Psychologia poznawcza. Znak-Język-Rzeczywistość. Warszawa, Polskie Towarzystwo Semiotyczne.

Maruszewski T. (2002), Psychologia poznania. Sposoby rozumienia siebie i świata. Gdańsk, GWP.

Maruszewski T. (2011), Psychologia poznania. Umyst i świat. Gdańsk, GWP.

Mrazek H. (2006), Mechanizmy czytania i rozumienia w świetle lingwistycznej teorii tekstu. „Nowa Polszczyzna", 1 (46).

Ożdżyński J. (red.) (1995), Językowy obraz świata dzieci i młodzieży. Kraków.

Reber A.S., Reber E.S. (red.) (2005), Stownik psychologii. Warszawa, Scholar.

Siuta J. (red.) (2005), Słownik psychologii. Kraków, Wydawnictwo Zielona Sowa.

Szalkowska A. (2008), Rozumienie niespójnej narracji. W jaki sposób z niespójnego przekazu konstruujemy spójny obraz rzeczywistości? „Nowa Polszczyzna”, 2 (56).

Szczepska-Pustkowska M. (2011), Od filozofii dzieciństwa do dziecięcej filozofii życia. Casus władzy (i demokracji). Kraków, Oficyna Wydawnicza Impuls.

Szewczuk W. (red.) (1968), Psychologia rozumienia. Warszawa, PWN. 
Szymczak M. (red.) (1995), Słownik języka polskiego. Warszawa.

Wasilewska A. (red.) (2007), Dziecko - teksty - znaczenia. Gdańsk, Wydawnictwo UG.

Wierzchoń M., Orzechowski J., Barbasz J. (2012), Interdyscyplinarność w naukach kognitywnych - science, fiction czy science fiction? W: A. Chmielewski, M. Dudzikowa, A. Grobler (red.), Interdyscyplinarnie o interdyscyplinarności. Między idea a praktyką. Kraków, Oficyna Wydawnicza Impuls.

Wiśniewska-Kin M. (2007), „Chcieć, pragnać, myśleć, wiedzieć”. Rozumienie pojęć przez dzieci. Kraków, Oficyna Wydawnicza Impuls.

Wiśniewska-Kin M. (2007), „Miłość jest jak wiatrak”, czyli o poznawczej naturze metafor dziecięcych. Łódź, Wydawnictwo UŁ.

Witoszek A. (1968), Badania nad rozumieniem w polskiej psychologii. W: W. Szewczuk (red.), Psychologia rozumienia. Warszawa, PWN. 